\title{
The relationship between shift work and sleep patterns in nurses
}

\author{
Relação entre trabalho por turnos e padrões de sono \\ em enfermeiros
}

Milva Maria Figueiredo De Martino ${ }^{1}$

Ana Cristina Basto Abreu ${ }^{2}$

Manuel Fernando dos Santos Barbosa ${ }^{2}$

João Eduardo Marques Teixeira ${ }^{2}$

${ }^{1}$ Departamento de enfermagem, Universidade Federal de São Paulo. Rua Renato Reis 56, Jardim América. 13084-445

Campinas SP.

martino.milva@unifesp.br

${ }^{2}$ Laboratório de

Neuropsicofisiologia,

Faculdade de Psicologia e

Ciências Educationais,

Universidade do Porto.

\begin{abstract}
The scope of this study was to evaluate the sleep/wake cycle in shift work nurses, as well as their sleep quality and chronotype. The sleep/ wake cycle was evaluated by keeping a sleep diary for a total of 60 nurses with a mean age of 31.76 years. The Horne \& Östberg Questionnaire (1976) for the chronotype and the Pittsburgh Sleep Quality Index (PSQI) for sleep quality were applied. The results revealed a predominance of indifferent chronotypes (65.0\%), followed by moderately evening persons (18.3\%), decidedly evening persons (8.3\%), moderately morning persons $(6.6 \%)$ and decidedly morning persons (1.8\%). The sleep quality perception was analyzed by the visual analogical scale, showing a mean score of 5.85 points for nighttime sleep and 4.70 points for daytime sleep, which represented a statistically significant difference. The sleep/ wake schedule was also statistically different when considering weekdays and weekends. The PSQI showed a mean of 7.0 points, characterizing poor sleep quality. The results showed poor sleep quality in shift work nurses, possibly due to the lack of sport and shift work habits.
\end{abstract}

Key words Sleep, Shift work, Nurses, Circadian rhythm, Worker's health
Resumo Este estudo teve como objectivo analisar o ciclo vigília-sono em enfermeiros que trabalham por turnos, bem como a qualidade do sono e cronótipo. O ciclo vigília-sono foi avaliado através do diário de sono, num total de 60 enfermeiros, com idade média de 31.76 anos. Para o cronótipo utilizou-se o Questionário de Horne e Östberg, de 1976, e para medir a qualidade de sono calculou-se o Índice Qualidade de Sono de Pittsburg (PSQI). Os resultados do cronótipo mostraram uma predominância para tipo indiferente (65.0\%), seguido do tipo Moderamente Vespertinos (18.3\%), Definitivamente Vespertino (8.3\%), Moderadamente Matutinos (6.6\%) e Definitivamente Matutinos (1.8\%). A percepção da qualidade do sono autorreportada pela Escala Analógica Visual (VAS) foi de 5.85 pontos, em média, para o sono nocturno e 4.70 para o sono diurno, diferença estatisticamente significativa. Os participantes demonstraram que o tempo de acordar e adormecer durante a semana o fim-de-semana foram estatisticamente diferentes. No PSQI obteve-se uma média de 7.0 pontos, caracterizando o sono como de má qualidade. Os dados permitiram classificar o sono dos enfermeiros como de má qualidade. A falta de hábitos desportivos e o esquema de trabalho em turnos poderão ter influenciado na qualidade de sono. Palavras-chave Sono, Trabalho em turnos, Enfermeiros, Ritmo circadiano, Saúde do trabalhador 


\section{Introduction}

Since the beginning of the XXI century, sleep has been studied with the purpose of clarifying its physiological meaning to the human life balance. The human body works in harmony with a biological clock, which rhythms vary according to environmental factors. Ultradian rhythms have short durations (seconds, minutes or hours), while circadian rhythms have a length of approximately 24 hours and are regulated by daylight ${ }^{1,2}$. The sleep-wake cycle is endogenously generated and regulated by a neural structure of the hypothalamus named suprachiasmatic nucleus, which is responsible for the biological clock in mammals ${ }^{3}$. Although the sleep-wake cycle is stable, there are some endogenous and environmental factors (light, sleep, food, among others) that lead to circadian variations $s^{4,5}$.

Work shift, in particular night shifts, may have strong psychological and physiological effects on the workers. It is associated with negative effects such as insomnia, decreased alertness, cognitive decrements, fatigue, mood disturbance, reproductive issues, increase in accidents and family, social and emotional problems $s^{5}$. Working on shifts may cause moodiness, since it induces a decrease in serotonin, a substance that regulates sleep, promotes good mood, and is released during the night. People who work at night have the secretion of this neurotransmitter decreased, leading to mood variation ${ }^{6}$. In addition, one electroencephalographic research involving a group of nurses working on shifts showed micro-awakenings in these subjects, characterizing their sleep as non-repairing ${ }^{7}$.

In relation to biological rhythmicity, there are some temporal allocation differences in circadian rhythms. Those differences are analyzed as morningness characteristics (early resource allocation) or as eveningness (late resource allocation) ${ }^{8}$.

According to Horne \& Östberg ${ }^{9}$, it is possible to classify people into three chronotypes regarding their allocation to the circadian rhythm: morningness (subdivided into moderate and extreme), indifferent and eveningness (also subdivided into moderate and extreme). Those comprising the morningness type prefer to sleep early, around $9 \mathrm{pm}$ or $10 \mathrm{pm}$, and also wake up early without difficulties, around $6 \mathrm{am}$, showing a good mental and physical performance, with alertness in the morning. Conversely, subjects who have the eveningness chronotype prefer to sleep and wake up later, around $1 \mathrm{am}$ and after $10 \mathrm{am}$, respectively, showing better disposition in the af- ternoon or in the evening. Regarding the indifferent type, people have more flexibility, designing their routines based on their schedules.

Therefore, chronotype classification consists in a simple method that considers individual circadian differences, sleep habits, performance at a specific daytime, among others. Thus, it is possible to plan work shifts based on individual chronobiological characteristics $^{10}$. Moreover, some of the shift work symptoms can be reduced if the shifts are aligned with individual endogenous circadian rhythms ${ }^{11}$. Given the above, we attempted to investigate patterns and sleep habits among nurses working on rotational shifts.

\section{Method \\ Participants}

The current study comprised 60 nurses aged $23-48$ years (mean: 31.76 years), 7 males (11.67\%) and 53 females $(88.33 \%)$, working in nocturnal and diurnal shifts in a public hospital in Oporto, Portugal. Each shift has about eight hours. Among the subjects, $50.0 \%$ were single, $43.3 \%$ married and $6.7 \%$ divorced. The majority (58.3\%) did not practice any sport while the remaining $41.7 \%$ practiced dance, gymnastics, walking, water aerobics, soccer or swimming. The research meets the ethical principles in research on Portugal.

\section{Materials}

The sociodemographic characteristics of the sample were acquired by a semi-structured interview. A sleep diary was used to evaluate sleepwake cycles, which included a visual analogue scale (VAS) scale used to evaluate sleep quality. The Morningness and Eveningness Questionnaire, by Horne \& Östberg ${ }^{9}$, was applied to evaluate chronotype. Both questionnaires were validated by Benedito-Silva et al. ${ }^{12}$. The Pittsburgh Sleep Quality Index (PSQI) was used to estimate quality and sleep patterns ${ }^{13,14}$.

\section{Procedures}

The nursing chief authorized the acquisition of data, which took place from November 2010 to April 2011.

Once the informed consent document has been signed, participants were individually interviewed and answered all questionnaires. The sleep 
diary was applied during six days, including weekdays and weekends.

Diary scores were analyzed and later compared with correspondent scores obtained in PSQI, chronotype and sleep patterns.

\section{Statistical analysis}

The significance level was set at $p<.05$. The Wilcoxon test for nonparametric analysis of variance was used when comparing two related samples. The measures of correlation among some sleep pattern features were obtained by Pearson's correlation.

\section{Results}

Nurses were classified as follows: Indifferent chronotype $(65.0 \%)$ followed by moderately eveningness $(18.3 \%)$, definitely eveningness $(8.3 \%)$, moderately morningness (6.6\%), and definitely morningness $(1.8 \%)$. Therefore, indifferent chronotypes had a higher incidence in the sample. These results are presented in Figure 1 below.

The PSQI Questionnaire results showed that $31.7 \%$ of the participants were classified as having good quality sleep, while $68.3 \%$ reported bad sleep (see Figure 2).

Globally, the mean PSQI score was of 7.02 points $(S D=2.87)$, which characterizes sleep quality as poor.

We analyzed the number of times people usually wake up during the night. The results showed

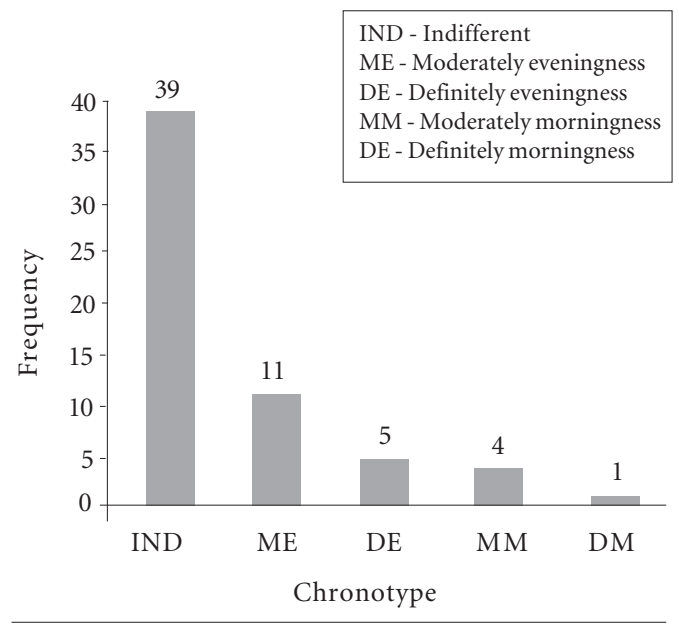

Figure 1. Distribution of nurses according to chronotype. that $48.1 \%$ of the sample did not report wake up episodes during the night, but $51.8 \%$ reported at least one wake up episode.

Table 1 shows the descriptive variables studied by the sleep diary, in a six-day period, including weekends and weekdays. Latency is the period of time between going to bed and falling asleep.

Regarding daytime and nighttime sleep, the mean between waking up on weekdays and weekends was statistically different (Wilcoxon test, $p$ $<.001)$. It was verified that the daytime sleep quality was worse, showing a statically significant difference as well (Wilcoxon test, $p=0.004$ ).

It was also found significant correlation between sleep latency and PSQI $(r=.349, p=.006)$,

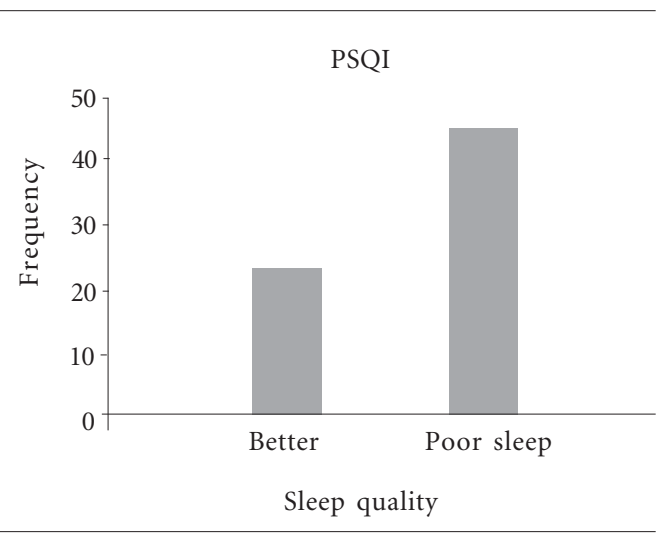

Figure 2. Distribution of sleep quality in nurses according to the PSQI score.

Table 1. Variables of the sleep pattern of the day and night sleep during the week and weekends

\begin{tabular}{|c|c|c|c|}
\hline \multicolumn{2}{|c|}{ Variables } & \multirow{2}{*}{$\begin{array}{c}\text { Mean }(\mathbf{h}) \\
7,51\end{array}$} & \multirow{2}{*}{$\begin{array}{c}\text { SD (h) } \\
1,03\end{array}$} \\
\hline Night Sleep & Total of sleep hour & & \\
\hline & Sleep Quality & 5,85 & 1,66 \\
\hline \multicolumn{4}{|c|}{ Wake up hour } \\
\hline & Week days & 7,78 & 1,45 \\
\hline & Wekends & 8,95 & 1,77 \\
\hline \multicolumn{4}{|c|}{ Wake up hour } \\
\hline & Week days & 23,94 & 1,14 \\
\hline & Wekends & 24,62 & 1,30 \\
\hline \multirow[t]{6}{*}{ Day Sleep } & Total of slept hour & 3,77 & 1,85 \\
\hline & Sleep quality & 4,70 & 1,88 \\
\hline & Wake up hour & 16,57 & 1,78 \\
\hline & Wake up hour & 12,83 & 2,54 \\
\hline & Latency & 0,54 & 0,30 \\
\hline & Feel to wake up & 5,30 & 1,59 \\
\hline
\end{tabular}


latency and VAS $(r=.29 ; p=.022)$, as well as between PSQI and VAS $(r=-.432 ; p=.001)$.

Positive significant correlations were found between feeling awake and sleep quality measured by VAS $(r=.732, p<.001)$ (Figure 3a). It was also found a positive correlation among the awakening hour, sleep hour $(r=0.518, p=.001$, Figure $3 \mathrm{~b})$ and the number of hours slept at night $(r=$ $.518, p<.001)$.
Significant negative correlations were found between chronotype and sleep hour $(r=-.600$; $p$ $<0.001)$-Figure 4a awakening hour $(r=-.511 ; p$ $<0.001)$ - Figure $4 \mathrm{~b}$ and number of hours slept $(r=-0.386 ; p=0.024)$. It was also showed a statistically significant negative correlation between age and the awakening hour $(r=-0.348 ; p=$ 0.006), i.e., older subjects usually wake up earlier than young subjects.
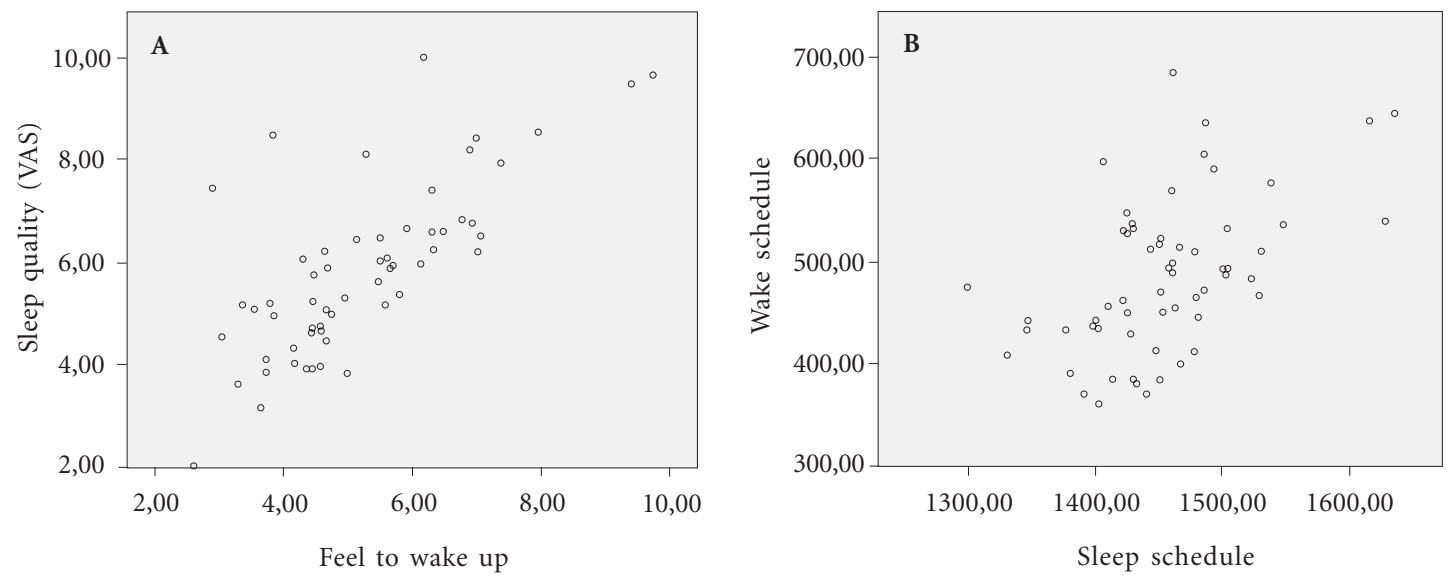

Figure 3. Positive Correlations between variables A) Feel to wake up and night sleep and B) Sleep Schedule and wake schedule.
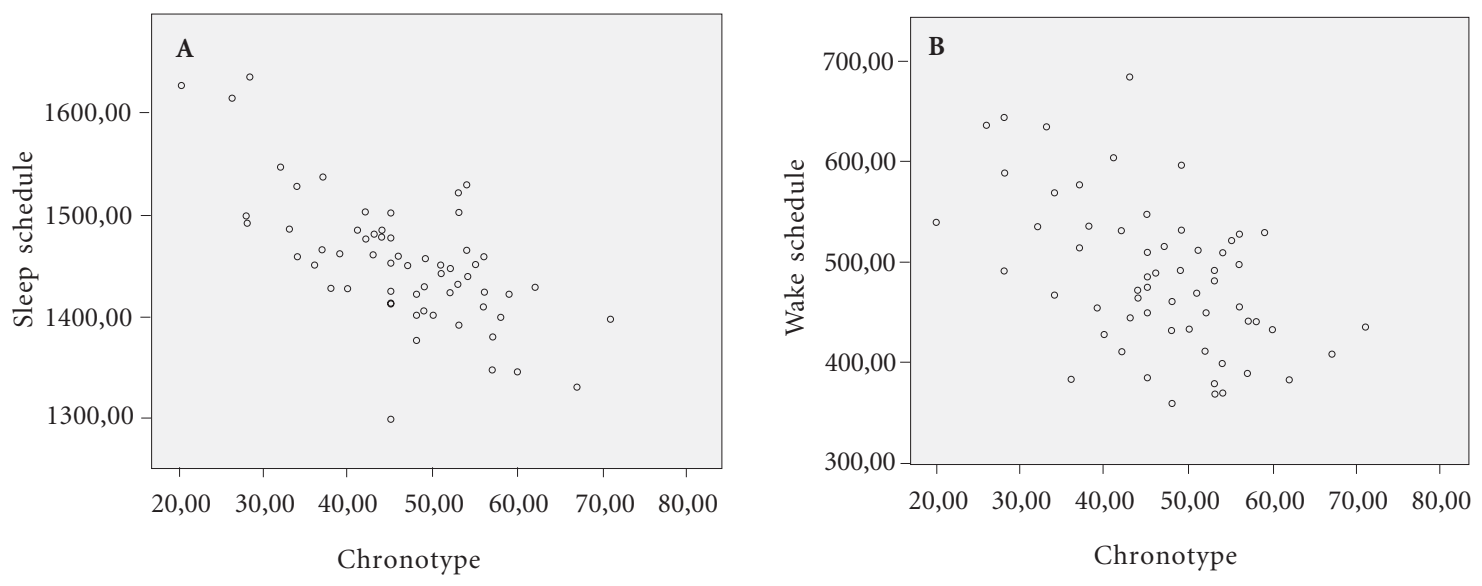

Figure 4. Negative correlations between Chronotype and a) Sleep Schedule and b) Wake schedule. 


\section{Discussion}

Observing Figure 1, which points out chronotype, it is possible to conclude that the indifferent type was prevalent (approximately 65\%). These results are in agreement with the literature, suggesting a relation between sleep schedules and work routines and, possibly, that people have the ability to adjust their types of sleep to their work demands ${ }^{10}$. Nurses have no fixed timetable, and namely at the beginning of their careers, they must change and manage their schedules according to their shifts.

We have used two instruments to analyze sleep quality: PSQI and Visual Analogue Scale (VAS). Although VAS has presented regular sleep, PSQI showed the opposite. The value obtained in PSQI characterizes sleep as poor (Figure 2). More than 30 minutes to fall asleep also suggests that the studied nurses had a poor quality sleep. In fact, nearly two-thirds of the sample presented poor sleep in PSQI, a characteristic that is usually found in populations who work rotating shifts. This result is in accordance with some researches ${ }^{15-18}$, which emphasize that hospital is one of the most complex organizations, requiring a refined range of technical skills, being also essential some features such as attention, affection, patience and empathy to patients.

In this study, it is reported that nurses have different schedules at weekends. In fact, at weekends, people usually need to spend more time with their families and friends, coupled with the fact that, since they do not have to go to the hospital, they might prolong the sleep period until late in the morning. In general, the distribution of days-off follows this social routine, considering the nursing service efforts to reduce the number of nurses during the weekends.

It is possible to conclude that subjects who have eveningness chronotype show a tendency to go to bed late and wake up late. Conversely, subjects who have high scores of chronotype show a tendency to go to bed early and wake up also early. In addition, in this sample, people who have high score of chronotype show a predisposition to sleep fewer hours.

It is demonstrated that the quality of daytime sleep is worse when comparing with nighttime sleep. De Martino ${ }^{7}$ demonstrated that the daytime sleep had poor quality because of the high number of micro-awakenings, as well as environmental sounds and factors, such as the daylight.

One of the limitations of this study was the lack of polysomnographic exam, which would com- plement the sleep pattern regarding their physiological aspects, namely the exact parameters of daytime and nighttime sleep of nurse population. Thus, it would be possible to identify the synchronization between the biological rhythms and the shift work in the standpoint of chronobiology.

\section{Conclusion}

The data have shown a poor sleep quality in nurses working shifts. Several factors might contribute to the poor quality of sleep, as for example the lack of physical exercise, the scheme of working shifts and the specific nursing work for the patient care.

Analyzing chronotypes, it was possible to conclude that the indifferent type was prevalent, confirming that people have the skill to adjust the schedules according to their work routines.

The schedule to wake up and fall asleep on weekdays and weekends was statistically different, suggesting that people do not have the necessary resting time during the week.

Based on the results of this study and others, it is possible to suggest that individual chronobiological characteristics are considered when scheduling work shifts for nurses, making possible an improvement in their working conditions.

\section{Collaborators}

MMF De Martino and ACB Abreu participated in the desing, analysis data and final writing. MFS Barbosa was critical reviewer and participated data analysis. JEM Teixeira reviewer was critical and guiding.

\section{Acknowledgement}

This research was supported by a grant from the MUNDUS 17 Program. 


\section{References}

1. Cipolla-Neto J, Marques N, Menna-Barreto L. Introdução ao estudo da Cronobiologia. 2a Edição. São Paulo: Ícone; 1988.

2. Lamont EW, Amir S. Circadian and Ultradian Clocks/ Rhythms. In: George FK, Michel Le M, Richard FT, editors. Encyclopedia of Behavioral Neuroscience. Oxford: Academic Press; 2010. p. 257-261.

3. Aschoff J. Circadian rhythms: general features and endocrinological aspects. In: Kriegger DT, editor. Endocrine rhythms. Nova York: Revan Press; 1979. p. 1-29.

4. Almondes KM, Araújo JF. Padrão do ciclo sonovigília e sua relação com a ansiedade em estudantes universitários. Estudos de Psicologia 2003; 8(1):37-43.

5. Akerstedt T. Psychological and psychophysiological effects of shift work Scand. J Work Environ Health 1990; 16(Supl. 1):67-73.

6. Aloé F, Junior-Biagini JC, Tavares S. Parassonias diagnóstico e tratamento. Revista Diagnóstico \& Tratamento 2002; 7(3):22-29.

7. De Martino MMF. Arquitetura do sono diurno e ciclo vigília-sono em enfermeiros nos turnos de trabalho. Rev Esc Enferm USP 2009; 43(1):194-199.

8. De Martino MMF, Pasetti KFDM, Bataglion C, Ceolim MF. Morningness/eveningness chronobiological assessment of Dental students: chronotype. Sleep Science 2010; 3(1):7-10.

9. Horne JA, Ostberg O. A self-assessment questionnaire to determine morningness-eveningness in human circadian rhythms. Int J Chronobiol 1976; 4(2):97-110.

10. De Martino MMF, Silva CAR, Miguez SA. Estudo do cronótipo de um grupo de trabalhadores em turnos. Revista Brasileira de Saúde Ocupacional 2005; 30(111):17-24.

11. Bjorvatn B, Pallesen S. Practical approaches to circadian rhythm sleep disorders. Sleep Medicine Reviews 2009; 13(1):47-60.
12. Benedito-Silva AA, Menna-Barreto L, Marques N, Tenreiro S. A self-assessment questionnaire for the determination of morning-eveningness types in Brazil. In: Haynes DK, Pauly JE, Reiter RJ, editors. Chronobiology: its role in clinical medicine, general biologic and agriculture, part B. New York: WileLiss; 1990. p. 89-98.

13. Buysse DJ, Reynolds CF, Monk TH, Hoch CC, Berman SR, Kupfer DJ. The Pittsburg Sleep Quality Index: a new instrument for psychiatric practice and research. Psychiatry Res 1989; 28(2):193-213.

14. Carpenter JS, Andrykowski MA. Psychometric evaluation of the Pittsburg sleep quality index. Journal Psych Res 1998; 45(1):5-13.

15. Barboza JIRA, Moraes EL, Pereira EA, Reimão NAA. Evaluation of the sleep pattern in Nursing professionals working night shifts at the Intensive Care Units. Einstein 2008; 6(3):296-301.

16. De Martino MMF, Basto LM. Qualidade do sono, cronótipos e estado emocional, o caso de enfermeiros portugueses que trabalham por turnos. Pensar em Enfermagem 2009; 13(1):49-60.

17. Winwood PC, Lushington K. Disentangling the effects of psychological and physical work demands on sleep, recovery and maladaptive chronic stress outcomes within a large sample of Australian nurses. J Adv Nurs 2006; 56(6):679-689.

18. Silva RS, Silva I, Silva RA, Souza L, Tomasi E. Atividade física e qualidade de vida. Cien Saude Colet 2010; 15(1):115-120.

Artigo apresentado em 13/09/2011

Aprovado em 10/01/2012

Versão final apresentada em 1201/2012 